\title{
Haematological profile of crossbred Malabari goats in peripartum period
}

\author{
Rejitha $^{1}$, J. and Karthiayini ${ }^{2}$, K. \\ ${ }^{I}$ (Department of Veterinary Physiology, Kerala Veterinary and Animal Sciences University, India) \\ ${ }_{2}^{2}$ (Department of Veterinary Physiology, Kerala Veterinary and Animal Sciences University, India)
}

\begin{abstract}
This study was performed to evaluate the effect of peripartum period on haematological parameters using eight non pregnant and eight pregnant does (100-110 th day of pregnancy to one week after kidding). Haematological analysis included haemoglobin concentration (Hb), packed corpuscular volume (PCV), total erythrocyte count (TEC), mean corpuscular volume (MCV), mean corpuscular haemoglobin (MCH) and mean corpuscular haemoglobin concentration (MCHC). The whole data were analyzed using computerized software program SPSS Ver. 17.0. Haemoglobin concentration was the only haematological parameters that showed a higher significant $(P<0.01)$ difference in does during the peripartum period than the non pregnant $(9.17 \pm 0.11 \mathrm{~g}$ $\%)$ does. While there were no significant differences $(P>0.05)$ observed in other haematological parameters. So study indicates that haematological imbalances are unlikely to occur during peripartum period in crossbred Malabari does when properly managed.
\end{abstract}

Key words: crossbred Malabari does, haematological parameters, peripartum period

\section{Introduction}

Haematological parameters are good indicators of the physiological status of animals and its changes are of value, in assessing the response of animals to various physiological stressful situations like pregnancy and lactation. Metabolic changes that occur during pregnancy may alter physiological range of blood constituents and reflects the influence of physiological stress and level of adaptation (Al-Eissa et al., 2012). There are some reports that nutritional status and management practices also influence the physiological attributes and ability to cope with stress (Iriadam, 2007). So the aim of this study was to evaluate the effect of pregnancy and lactation on hematological parameters of Malabari crossbred goats maintained in standard goat rearing system.

\section{Materials and Methods}

The study was conducted using animals maintained in University Goat and Sheep Farm, Mannuthy in eight crossbred Malabari pregnant does (G1 group) from $100-110^{\text {th }}$ day of pregnancy and eight non pregnant does (G2 group). But the groups of animals were selected at random from the flock maintained in the farm, were aged between one to six years. All animals were apparently healthy, dewormed before mating and vaccinated routinely against infectious diseases like foot and mouth Disease, hemorrhagic septicemia and enterotoxemia. All animals were maintained on standard goat ration and allowed for $5 \mathrm{~h}$ daily free range grazing.

From non pregnant animals (G2 group) whole blood and serum were collected once. From pregnant animals (G1 group) blood was collected at different stages of pregnancy (100-110 day, 114-124 day and 128138 day), within $12 \mathrm{~h}$ of kidding and one week after kidding. Blood samples were collected from animals from 8.15 to 9.00 a.m. prior to morning feeding, by jugular venipuncture with sterile scalp vein, using Sodium EDTA @ $1.5 \mathrm{mg} / \mathrm{ml}$ of blood as anticoagulant.

Total erythrocyte count (TEC), haemoglobin (Hb) concentration and packed cell volume (PCV) were estimated and erythrocytic indices were calculated as per the standard technique described by Schalm (1986). Data collected on various parameters were statistically analyzed as per the method of Snedecor and Cochran (1994) using computerized software program SPSS Ver. 17.0. using independent t- test for comparing G1 (pregnant) group of animals at various physiological stages with G2 (non pregnant) group of animals.

\section{Results and Discussion}

$\mathrm{Hb}$ concentration of pregnant animals were significantly $(\mathrm{P} \leq 0.01)$ higher than that of non pregnant animals $(9.17 \pm 0.11 \mathrm{~g} \%)$. The high $\mathrm{Hb}$ level noticed was in accordance with the observations of El-Sherif and Assad (2001). The high $\mathrm{Hb}$ level noticed might be to meet the increased oxygen demand associated with enhanced metabolic activity during pregnancy. But no significant difference was observed in values of PCV, TEC, MCV, MCH and MCHC between the non pregnant and pregnant group of animals. El-Ebissy (2011) noticed no significant variation in values of $\mathrm{Hb}, \mathrm{MCV}, \mathrm{MCH}$ and TEC in Black head and Merino ewes during 
five and one week before kidding and four week after kidding, indicating animals were capable to adapt pregnancy related physiological stress.

Table I. Haematological parameters of pregnant and non pregnant cross bred Malabari goats

\begin{tabular}{|c|c|c|c|c|c|c|}
\hline \multirow[b]{2}{*}{ Parameters } & \multicolumn{5}{|c|}{ G1 group of animals } & \multirow{2}{*}{$\begin{array}{l}\text { G2 group of } \\
\text { animals (Non } \\
\text { pregnant) }\end{array}$} \\
\hline & $\begin{array}{c}100-110 \text { day of } \\
\text { pregnancy }\end{array}$ & $\begin{array}{c}\text { 114-124 day of } \\
\text { pregnancy }\end{array}$ & $\begin{array}{c}\text { 128-138 day of } \\
\text { pregnancy }\end{array}$ & $\begin{array}{c}\text { On day of } \\
\text { kidding }\end{array}$ & $\begin{array}{c}\text { Seven day after } \\
\text { kidding }\end{array}$ & \\
\hline $\mathrm{Hb}(\mathrm{g} \%)$ & $9.24^{\mathrm{b}} \pm 0.44$ & $9.5^{\mathrm{b}} \pm 0.32$ & $9.25^{\mathrm{b}} \pm 0.28$ & $9.22^{b} \pm 0.38$ & $9.22^{b} \pm 0.66$ & $9.17^{\mathrm{a}} \pm 0.11$ \\
\hline PCV (\%) & $26.33^{\mathrm{a}} \pm 1.69$ & $25.00^{\mathrm{a}} \pm 0.77$ & $25.75^{\mathrm{a}} \pm 0.80$ & $24.56^{\mathrm{a}} \pm 1.25$ & $23.67^{\mathrm{a}} \pm 1.51$ & $26.17^{\mathrm{a}} \pm 0.87$ \\
\hline $\begin{array}{l}\text { TEC } \\
\left(\times \mathbf{x} 10^{6} / \mu \mathrm{L}\right)\end{array}$ & $12.09^{\mathrm{a}} \pm 1.20$ & $11.46^{\mathrm{a}} \pm 0.58$ & $11.89^{\mathrm{a}} \pm 0.71$ & $11.25^{\mathrm{a}} \pm 0.91$ & $11.14^{\mathrm{a}} \pm 1.01$ & $12.56^{\mathrm{a}} \pm 0.63$ \\
\hline MCV (fL) & $22.13^{\mathrm{a}} \pm 0.69$ & $21.9^{\mathrm{a}} \pm 0.40$ & $21.94^{\mathrm{a}} \pm 0.70$ & $22.33^{\mathrm{a}} \pm 0.78$ & $20.28^{\mathrm{a}} \pm 0.24$ & $20.93^{\mathrm{a}} \pm 0.51$ \\
\hline $\mathrm{MCH}$ (pg) & $7.77^{\mathrm{a}} \pm 0.63$ & $8.35^{\mathrm{a}} \pm 0.41$ & $7.93^{\mathrm{a}} \pm 0.41$ & $8.59^{\mathrm{a}} \pm 0.67$ & $7.59^{\mathrm{a}} \pm 0.49$ & $7.37^{\mathrm{a}} \pm 0.31$ \\
\hline $\begin{array}{l}\mathrm{MCHC} \\
(\mathrm{g} \%)\end{array}$ & $34.91^{\mathrm{a}} \pm 2.06$ & $38.09^{\mathrm{a}} \pm 1.46$ & $36.0^{\mathrm{a}} \pm 1.18$ & $38.11^{\mathrm{a}} \pm 1.88$ & $37.26^{\mathrm{a}} \pm 0.87$ & $35.16^{\mathrm{a}} \pm 0.80$ \\
\hline
\end{tabular}

a, b Means within a row with no common superscripts are significantly different between G1 pregnant group of animals in various physiological state, to non pregnant $\mathrm{G} 2$ group of animals at $1 \%$ level

\section{Conclusion}

Peripartum period is a period of transition from non productive state to productive state. Although peripartum period is considered as one of the physiologically stressful condition, animals have the ability to adapt physiologically in terms of haematological parameters and cope with pregnancy related stress. This present study has indicated that haematological imbalances are unlikely to occur during pregnancy in Malabari crossbred does when properly managed.

\section{References}

[1]. M.S. Al-Eissa, S. Alkahtani, H. Al-Yahya and M. AL-Marzoug, M. Effect of pregnancy on haematological and biochemical profiles in the mountain gazelles (Gazella gazelle). Curr. Res. J. Biol. Sci. 4(4), 2012, 526-532.

[2]. M. Iriadam. Variation in certain hematological and biochemical parameters during the peri-partum period in Kilis does. Small Ruminant Res. 73(1), 2007, 54-57.

[3]. O.W. Schalm, N.C. Jain and E.J. Carroll, Veterinary Haematology. 4 (Philadelphia: Lea and Febiger, 1986) 45-48.

[4]. G.W. Snedecor and W.G. Cochran, Statistical Methods. 8 (Calcutta: Oxford and IBH Publishing company, 1994) 550- 564.

[5]. M.M.A. El-Sherif and F. Assad, Changes in some blood constituents of Barki ewes during pregnancy and lactation under semi arid conditions. Small Ruminant Res. 40(3), 2001, 269-277.

[6]. E.A.E.M. El-Ebissy, Relationship between metabolic parameters and TNF $\alpha$ in the peripartal period in ewes, M.V.Sc. thesis, University of Leipzig, Cairo, 2011. 